Kom, 2016, vol. V (1) : 1-20

UDC: 14 Беме J.

28-1:141.332

DOI: $10.5937 /$ kom1601001P

Original scientific paper

\title{
A Wild Tree toward The North - JACOB BOEHME's THEOSOPHICAL VISION OF ISLAM
}

\author{
Roland Pietsch \\ Ukrainian Free University, Munich, Germany
}

\begin{abstract}
Jacob Boehme, who was given by his friends the respectful title "Philosophus Teutonicus", is one of the greatest theosophers and mystics at the beginning of the seventeenth century, whose influence extends to the present day. He was born in 1757 in the village Alt-Seidenberg near Görlitz, in a Protestant family of peasant background. Boehme spent most of his life in Görlitz, as a member of the Cobbler's Guild. His first mystical experience was in 1600, when he contemplated the Byss and the Abyss. Published in 1612, "Aurora: the Day-Spring (Morgenröte im Aufgang)" was Boehme's first attempt to describe his great theosophical vision. It immediately incurred the public condemnation of Görlitz's Protestant Church. He was forbidden to write further. Boehme kept silent for six years and then published "A Description of the Three Principles of the Divine Essence (Beschreibung der drei Prinzipien göttlichen Wesens)" in 1619 and many other works. A large commentary of Genesis, "Mysterium Magnum” came out in 1623, followed by "The Way to Christ (Der Weg zu Christo)" in 1624. In the same year Jacob Boehme died on November $20^{\text {th }}$ in Görlitz. According to his own self-conception, Boehme's doctrine of divine wisdom (Theo-Sophia) is a divine science which was revealed to him in its entirety (see Pietsch: 1999, 205-228). Boehme's extensive works are characterised by continually new approaches to the task of developing the entirety of this vision. Although his writings deeply influenced some of the most significant thinkers such as Gichtel, the Cambridge Platonists, Newton, Leibniz, Blake, Hegel, Schelling, Novalis, Franz von Baader and Berdyaev, many aspects of Boehme's thought have remained unexamined until today. That Boehme's comprehensive approach also necessitated the incorporation of a world religion such as Islam into his view of salvation history (Heilsgeschichte) is a point that has not received sufficient attention. This article will summarise and consider his views relating to the subject.
\end{abstract}

Corresponding author: roland.pietsch@t-online.de 
Keywords: Jacob Boehme, Theosophy, Mysticism, Christianity, Islam, Ishmael, Abyss or Unground, salvation history (Heilsgeschichte), transcendent unity of religions

\section{Introduction}

How Jacob Boehme $e^{1}$ understood Islam and what significance he awarded the religion in the history of humankind is a question best answered with reference to his metaphysical, i.e. meta-historical and eschatological doctrine. These two doctrines are important aspects of his doctrine of divine wisdom and can only be understood in the larger context of his thought. Here Boehme begins with the concept of the divine desire for self-revelation, which brought the world and humanity into being. Boehme sees the creation of the world in the motion of the divine Father, the incarnation of Christ in the motion of the Son and the end and fulfilment of time in the motion of the Holy Spirit. It is in these three motions, based on the doctrine of the epochs of the Father, the Son and the Holy Ghost, that the meta-historical, metaphysical source of world history is hidden. Boehme never distinguishes between this foundation of world history and salvation history. For an undestanding of the relation between the meta-historical foundation of salvation history and its course and thus the meaning of Islam within this schema, a summary presentation of Boehme's doctrine of divine wisdom will be given. This will be followed by a discussion of the position of Islam in the salvation history as conceived by Boehme.

\section{Jacob Boehme's Doctrine of Divine Wisdom}

Jacob Boehme's doctrine of divine wisdom relates to the absolute and unconditional reality of God, which he also refers to as the "Abyss" or "Unground (Ungrund)". In the "Unground" there is "nothing but a stillness without being; neither is there anything that can give anything; it is an eternal rest without parallel, a groundlessness without beginning and end" (Boehme 1659: II/1, 8.), which does not reveal itself.

1 On the life and work of Jacob Boehme see: Hamberger 1844, Hankamer 1924, Peuckert 1924, Koyré 1929, Benz 1937, Grunsky 1956, Stoudt 1957, Solms-Rödelheim 1960, Walsh 1983, Deghaye 1985, Weeks 1991, Bonheim 1992, Cuniberto 2000. 


\section{1. The Self-revelation of God}

Boehme uses the will of the "Unground" to help explain the self-revelation of divine reality. The will of the "Unground" is distinct from the "Unground" itself and forms the view of the divine reality that wishes to reveal itself both inwardly and outwardly. However, the will of the "Unground", which does not reveal itself in an immediate sense, conveys itself through its self-substantiation or its self-comprehension. Boehme uses the divine trinity to explain the process of this self-containment; he names the incomprehensible will of the "Unground" Father, the comprehensible will which is equal to the incomprehensible will Son, and the issuing of the incomprehensible will through the comprehensible will or "Ground" Spirit. This trinity sees itself in the mirror of its wisdom. This process of self-comprehension can also be described as the eternal realisation or self-knowledge of God. In other words, God realises himself and knows himself in the mirror. In this first phase of the eternal self-revelation or self-knowledge of God, described by Boehme as clear divinity, eternal trinity or free desire, there is only one ruling element: "The one will, that is to say, the one God who brings himself into a threefoldness as into an apprehensibility of himself. This apprehensibility is the centre, as the eternal apprehended One, and is called the heart or seat of the eternal will of God, in which the "Unground" possesses itself in a ground. And it is the one place of God, but with no partition or separation" (Boehme 1655: 1, 9); i.e. this phase of clear divinity or free desire is free from dichotomies, for God has conveyed Himself out of the un-conditionality into the selfconditionality of his own source or heart. The abundance of characteristics and forces still lies, still and unseparated, in the singular force of the will of the "Unground". However, the self-comprehension of the will gives rise to the yearning to reveal the abundance of characteristics and forces hidden within and to enunciate them openly. This yearning awakens the desire which consists of the contraction of the will into itself, so that the unseparated and hidden forces can attain their own quality and form, in which they can reveal themselves. With this process, and the unification of yearning and desire (Lust und Begierde), the eternal nature arises within God. In the divine self-revelation this becomes simultaneously the location from which God brings everything that he sees as possibility in the mirror of wisdom into effective reality. Thus God reveals himself outwardly, although this does not yet imply the creation of the world and humanity.

The revelation of God through eternal nature is described by Boehme with reference to his doctrine of the seven forms of nature, all of which interpenetrate and influence one another. The first form is the desire or contraction, which gives rise to darkness. This first form gives rise to the second 
form, or the "bitter pang" (Bitterstachel), of movement or expansion. From the dichotomous interaction of contraction and expansion the third form is born, that of anguish, in which the will of the "Unground" desires to return to the freedom of the "Unground" in order to be free from this anguish. With the eternal will of the "Unground" the freedom comprehends the darkness, "and the darkness grasps for the light of freedom and cannot reach it, then it recoils back into itself, back into darkness" (Boehme 1651: 14, 22). From this dichotomy the fire bolt breaks forth. This is the fourth form of nature, in which unity receives sensitivity and the will of nature receives gentle unity. "In this kindling darkness...is pierced (durchdrungen) through with light, so that it is no more known or discerned" (Boehme 1647: IX/51).

This surmounting of the darkness of the first three forms of nature does not imply the destruction of their source. It gives rise to two forms or principles of revelation; that of light and that of fire. The force of light, which has overcome the darkness, reveals itself in the fifth form of nature as the fire of love, which is born out of the remaining forms of nature, through the mediation of the fourth form. The fifth form in the scientia is the "true love-fire, which separates itself in the light from the painful fire, and therein the divine Love in being is understood" (Boehme 1655:3,26). This form contains all the forces of divine wisdom within itself. In the sixth form the forces that were implicit in the fifth form become separate from one another. With their separation they also become perceptible; there is a rejoicing of the forces and "characteristics within one another; each delights in the other and thus love arrives at unity in will and effect" (Boehme 1654: I/Table). In the seventh form of nature, which is understood as the aggregation of all the other characteristics, the third principle reveals itself. By the third Principle we may also understand the seven properties of nature, as "these are brought in the seventh into one being and so to an inclusion. This being, in itself holy, is pure and good" (Boehme 1655: 4, 10). As the eternal nature in God the seventh form of nature is also the body of God, although not in the sense of a physically tangible being.

The will of the "Unground" as the Father who rules the first principle or the fire gives eternal birth to the Son by means of the seven forms of nature. The Son, who reveals himself in the second principle of light, eternally exalts the Father. The Holy Ghost, who reveals himself in the third principle, is eternally issued from the Father and Son, who emits the brilliance of the divine glory. "The Eternal Father is manifested in the fire, and the Son in the light of fire, and the Holy Spirit in the power of the life and motion proceeding from the fire in the light of the kingdom of joy, being the egressive power in the love-flame... The Deity is wholly everywhere all in all; but he is only called God according to the light of love, and according to the dark impression 
he is called God's anger and dark world; and according to the eternal fire-spirit he is called a consuming fire" (Boehme 1651: 14, 35). God's love and wrath are not irrevocably opposed to one another, however; rather, love is devoured within the wrath and both exist within one being. Boehme depicts the interplay of the seven forms of nature and the three principles in the eternal spiritual nature in the following schema:

\section{The seven forms of nature}

\begin{tabular}{|c|c|}
\hline I. acerbity, desire, will & \multirow{3}{*}{ 1. dark world } \\
\hline II. "bitter pang"( Bitterstachel) & \\
\hline III. anguish, leading to the fire-bolt & \\
\hline $\begin{array}{ll}\text { IV. } & \text { (dark fire) } \\
\text { fire-bolt } \\
\text { (light-fire) }\end{array}$ & 2. dark (fire-)world \\
\hline $\begin{array}{l}\text { V. light or love, from which the water } \\
\text { of eternal life flows }\end{array}$ & \multirow{3}{*}{ 3. light-world } \\
\hline VI. sound or tone & \\
\hline VII. being or nature & \\
\hline
\end{tabular}

Three principles

The first principle, dark world

From here onwards God is referred to as a wrathful, jealous and consuming fire.
The second principle,

light world

God as the son:

Word: Heart of God:

From here onwards referred to as the loving and merciful God.

The third principle, which is this world arisen from the first and second principle.

Here the light and darkness, good and evil, interpenetrate one another. 


\section{2. The creation of the world, and humanity and the Fall}

God did not create the world, the angels, humanity and all the creatures that he has recognised in the mirror of his wisdom throughout eternity "that he should be thereby perfect, but for his own manifestation, viz. for the great joy and glory" (ibid.: 16,2). The process of creation takes place through the first form's transformation of everything which appears in the mirror of wisdom into being and creaturely form: "not taken from alien matter, but from God's essence, or from the nature of the Father. And they were with God's Will-spirit introduced into the light of Majesty, where they were then children of God and not strangers, and were born and created from the Fathers' nature and property, and the spirit of their will was directed to the Son's nature and property" (Boehme 1659: I/2, 6). In other words, "the manifest world is the third principle, as the third ground and beginning; this has been breathed out of the first two (principles), from the inner ground, and brought into creaturely form and fashion" (Boehme 1647: 127). Thus the first creatures are the angels, created out of light and fire. However, in order to be able to live in God's light and power, they must sacrifice their fire life for God. Boehme describes this process, which is also relevant for humanity, in great detail: "But if it desires to plunge into the nothing, into freedom, it must abandon itself to fire; and then it sinks down in the death of the fire principle, and buds forth out of the anguish of fire in the light. For when it abandons itself, the eternal will to Nature (which is God the Father) leads it out through fire into himself. For with the abandoning it falls unto the first will to Nature, who brings it by the other will, which is his Son or Heart, out of the anguishful Nature, and places it with the Son's will in freedom" (Boehme 1920: 5, 7, 6). Lucifer, the most beautiful and most powerful angel, however, did not cast himself into the fire in humility but sought instead to ascend even above God himself. This arrogance caused him to be transformed into a dark devil. A battle between Lucifer and the archangel Michael was waged in the heavens in which Michael eventually triumphed with his legions. However, because the angels who had been expelled had ignited and destroyed the natural world, God recreated nature in six creation days and created man, whom he set in Lucifer's place as the ruler over nature. Whilst the angels are formed from two principles, man contains three principles within himself. His soul is grounded in the principle of darkness or fire, his mind or intellect in the principle of light and his body in the third principle. This first androgynous man was "clothed with the greatest glory, as with Paradise, a most beautiful clear crystalline image. He was not a man nor a woman, but both of these, viz. a masculine virgin" (Boehme 1655: 5, 35) in a perfect balance between fire and light. However, the primordial Adam loses this 
perfection in the moment when he ceases to centre his gaze on God and sets treacherous fantasies in his place. Thus his original balance is broken; weakened, he sinks into a deep sleep. It is from this state that the duality of Adam and Eve arises. The fall of the first human pair comes to its terrible conclusion when they succumb to the Devil through the tree of the knowledge of Good and Evil. Adam and Eve lose their heavenly existence and fall prey to death and darkness. But humanity, which is no longer in a position to redeem itself, is saved by God's mercy, in that "the heart of God moved itself and became man" (Bohme 1659: I/2, 9). In other words, God spoke his word into Adam's faded being and with these words the original spiritual will was quickened again in mercy. Thus God's wrath is overcome through God's love in the fallen Adam. Through His heart, that is, through His son, God has laid the ground for the new birth and eternal fulfilment of humanity.

\section{Islam and Its Position in Salvation History}

Already in his first work, "Aurora: the Day-Spring (Aurora oder Morgenröte im Aufgang)" (1612), Jacob Boehme refers twice to Islam, describing it as a "wild tree toward the north" (Boehme 1656: Preface 43). More detailed references to Islam are found later, in "A Description of the Three Principles of the Divine Essence (Beschreibung der drei Prinzipien Göttlichen Wesens)" (1619), "The Threefold Life of Man (Vom dreifachen Leben des Menschen)" (1620), "Concerning the Election of Grace (Von der Gnadenwahl)" (1623), and in "Mysterium Magnum" (1623) he presents a profound prophetic-mystical interpretation of this religion.

It is impossible to understand the position of Islam in Boehme's writings without an awareness of his mystical interpretation of the Holy Scriptures. Boehme makes particular use of the figurative interpretation with which he develops the main features of salvation history. In "Mysterium Magnum" Boehme pays particular attention to the most significant elements of this interpretation: "That whosoever will read and understand aright the history of the Old Testament, he must set before him two types, viz. externally Adam, viz. the earthly man, and internally Christ, and change both these into One... The Election of God passeth upon the figure only, shewing what <kind of $>$ people should bear the figure of the inward kingdom of Christ in the outward, in which people God would set forth and manifest the kingdom of Christ externally. The Jews have had only a mirror and type hereof externally, and so likewise the Christians, who looked upon Christ in the flesh as a mere pure man. These figures have remained very speechless to the world, even to 
this last time" (Boehme 1654: 46, 29-31; see Krause 1962: 126-280; Hilgenfeld 1971: 60-78, 150-173; Hiebsch 2002: 39-116).

\section{1. Main Elements of Salvation History}

The characteristics of the two principles of fire and light or wrath and love appear in Adam's descendants as the figure of Christ and Adam. They form two lines: "the line of the covenant" and "the line of miracles" (Boehme 1654: 14), which constantly work with and within one another throughout salvation history. The line of the covenant begins with Abel and is continued by Seth after the former was murdered by Cain, leaving no children. The line of miracles can be traced back to Cain. Whilst God's holy kingdom of the intellect is revealed in the line of the covenant, the line of the miracles reveals all manner of art and crafts. "In Cain the kingdom of nature was represented and in Abel and Seth the supernatural divine kingdom. Both of these arose together and interpenetrated one another, moving towards the contemplation of the divine yearning in the formed wisdom; and each put itself forth in an especial manner into its visible ken as a wonder" (ibid.: 30,13 ). Seven redemptive epochs were formed out of these two lines. The first is the epoch or time of Adam; this is followed by the epochs of Seth, Enos, Kenan, Mahalaleel, Jared and Henoch (see Benz 1935: 421-455). These seven epochs or time periods should not be understood as following one another in a chronological, historical sense but rather as being implicated in one another in a meta-historical sense. For each epoch has already been eternally present, but in a hidden fashion, in all the previous epochs. Thus the third time begins. This time should not be confused with the age of the Holy Spirit, "The third time begins with Enos, under Seth's time, and carrieth forth itself all along as a spiritual ministry, or knowledge of God, under Seth's time, as a hidden kingdom; and continues until Abraham, to whom the Covenant of Christ was established in the flesh" (Boehme 1654: 30, 36).

At the beginning of his interpretation of the biblical story of Abraham and his son Ishmael and Isaac, Boehme picks up the image of the two lines with the observation that God's son and the fallen Adam stand facing one another in Abraham and that God has "received Adam again in Abraham into his Covenant, word, and will" (ibid.: 40, 15). Therefore two lines, Ishmael and Isaac go forth from Abraham: "In the two brethren...both kingdoms are typified, viz. in Ishmael the kingdom of nature, and in Isaac the kingdom of grace" (ibid.: 40,2). The realm of nature takes its original state from the characteristic of the Father, i.e. from wrath, and must always "be the first, if a creature shall be brought forth <or to the producing of a creature>. Afterwards comes the kingdom of grace, which taketh in the nature; as first there 
must be a fire ere there be a light; the fire begetteth the light, and the light maketh the fire manifest in itself; it taketh the fire, viz. the nature into itself, and dwelleth in the fire" (ibid.: 40,2-3). With this symbolism of fire and light Boehme refers again to two principles within God, namely, the wrath of the Father and the love of the Son, "both of which are in one essence" (ibid.: 40, 4). With this he also indicates the actual metaphysical foundation for his figurative interpretation of the two brothers Ishmael and Isaac. The metaphysical origin of the dichotomy between fire and light, or wrath and love, for Boehme lies in the movement of divine characteristics, through which God moved nature and brought creatures into being. It is through creative motion that the two characteristics of wrath and love, which are unified in God, are separated into two opposing properties of nature. The meaning of this dichotomy lies for Boehme in "that when God moved the nature and created the creatures, the two properties, viz. of the love and the anger in nature, did sever themselves; so that the mystery of God, viz. the invisible spiritual world, might be manifest, and come into a wrestling <love-striving> sport, in the strife and counter-will. For if there were but one only will, then all essences would do but one thing; but in the counter-will each exalteth itself in itself to its victory and exaltation. And all life and vegetation stands in this contest, and thereby the divine wisdom is made manifest, and comes into form to contemplation, and to the kingdom of joy; for in the conquest is joy. But one only will is not manifest to itself, for there is neither evil nor good in it, neither joy nor sorrow; and if there were, yet the one, viz. the only will, must first in itself bring itself into a contrary, that it might manifest itself" (ibid.: 40, 7-8).

\section{2. Ishmael as the Image and Figure of Islam}

In accordance with this interfusion or opposing playfulness of the two eternal principles in God, the figures of these principles stand on the earthly level as "two wills manifested in one man" (ibid.: 40, 5), i.e. as the two brothers Ishmael and Isaac opposite one another. As will be shown more clearly later, Islam is evident in the figure of Ishmael. "In Ishmael the poor, sick, distempered, evil and corrupted Adam, fallen from the will of God was represented whilst in Isaac it is the image of Christ, which was come to help the poor corrupt Adam, and to introduce his apostate will into death and mortification, and purify the same again in the fire of God; and regenerate it anew in the love-fire, and in the first only eternal will of God, where the Father and the Son are one only will and essence in the wrathful anger-fire and in the lovelight-fire" (ibid.: 40, 6). Thus Boehme indicates the way to salvation, which leads through death in the fire of God to rebirth in light. The expulsion of 
Ishmael and his mother lead in the same direction. Banishment here does not refer to the expulsion from the child-father relationship with God, but only to the evil will. Boehme sees a maintaining of the interactivity, "For when Hagar was proud that she was with child and her mistress without and held Sarah in contempt for this reason Sarah punished her. But she fled from Sarah. Then the angel of the Lord met her, and said unto her, 'Hagar, Sarah's maid, whither wilt thou go? Return again to thy mistress, and humbly submit thyself unto her, I will so multiply thy seed that it shall not be numbered for multitude'. And the angel of the Lord said further unto her, 'Behold, thou art with child, and shalt bear a son, and his name shall be called Ishmael; because the Lord hath heard thy affliction. He shall be a wild man; his hand will be against every man, and every man's hand against him; and he shall dwell in the presence of all his brethren'. And she called the name of the Lord who spoke with her, 'Thou God seest me': for she said, 'Here I have seen him, who hath looked after me. Therefore she called the well where this was done, the well of the living who hath looked upon me' (Gen. XVI. 8-14)" (Boehme 1654: 40, 19-20).

Boehme gives a prophetic-mystical interpretation of this text. In view of the fact that it is precisely the taunter Ishmael who is promised a progeny so numerous that it cannot be counted, Boehme asks, "Why this taunter in particular?" before offering an answer himself: "Because in him lay the kingdom of the wonders of God's manifestation out of nature, viz. out of the fire-world, out of God's strength and omnipotence; which he will again introduce in Christ into the love, viz. into the only free One. But Hagar, viz. the will of the fire-soul's nature, must be converted and enter into repentance, humble itself before the free, viz. the only merciful love-will, viz. before the Covenant and seed in Isaac, and cast away the rebellions will from itself" (ibid.: 40, 24). Alongside the justification for the prophecy of a great progeny for Ishmael Boehme interprets the angel's command to Hagar as a command to turn to the one God. In this turning, which in the last instance is a turning back to the primordial religion of Abraham, Boehme also refers to Islam as the renewal of this religion. The mystical significance of the turning of Hagar lies in the fact that "the soul dieth to self-will" (ibid.: 40, 22), a state which she is not able to bring about by herself, unless "God look upon it again, as here happened to Hagar, when she said, Thou God seest me. And therefore she called this place or fountain the fountain of the living and seeing. For the fountain of life did even there manifest itself in her and brought her again to conversion" (ibid.: 40,33). With this reversal, which takes place through God's mercy, Boehme makes a reference to the turning of Ishmael, the grandeur of which he emphasizes in a number of texts, although he mainly relies on the divine blessing and prophecies, which were 
made to Ishmael according to the request of Abraham: "Behold, I have blessed him, and will make him fruitful, and multiply him exceedingly; twelve princes shall he beget; and I will make him a great nation (Gen. XVII. 20)" (Boehme 1654: 40, 34). Ishmael was expelled with his mother Hagar in order to prevent his inheriting the property of Abraham. He does not originate from the line of the covenant. However, he is still destined to receive the property of others. Isaac on the other hand, because he stems from the line of the covenant and had "Christ now in the Covenant from God's giving, as a natural right in himself" (ibid.: 40, 46), received Abraham's property. All the others who did not stand in the line of the covenant received what they were given through God's mercy alone. In addition to this, Ishmael was also destined to become part of the Covenant in Christ. "But now Ishmael must put on the Covenant from Christ, and not from the inherited adoption or childship, as Christ, who had it from God in a childlike <or filial> right. And now Ishmael must do this for the obtaining of it, viz. he must behold himself in the fountain of the seeing and living, as his mother Hagar did, and return again with the lost son to the Father, and fall down before Abraham's feet, that is, his heir, Isaac, in Christ; and pray that he would receive him into his house (which is Christ's humanity, viz. the spiritual world), as a servant and day-labourer; for he hath had no more any right to his inheritance; he hath been begotten and born only as a stepbrother of a strange mother, viz. of the kingdom of nature" (ibid.: 40, 57). Boehme uses the figure of the lost son to clearly indicate the return to the Father and refers to the necessary return when he says that Ishmael "cannot be born anew unless he die to his self, and his own willing, and come, in a converted will, to God in Christ, as the lost son, who neither wills nor desires anything from a natural proper right, but only that the Lord of the goods would have mercy on him, and receive him again to be a day-labourer. This converted will God doth take in, to his gracious, free-given inheritance, viz. into the goods of Abraham in Christ, and maketh it to be heir in Isaac's goods, viz. in Isaac's freely given inheritance in Christ" (ibid.: 40, 57). This radically changed the relation between Isaac, who had a natural right to the inheritance and Ishmael, who was excluded from it. As the lost son, Ishmael becomes an inheritor of divine munificence through "God's mercy" (ibid.: 40, 57). The father clothes him with "the finest raiment" (Luke 15,22) meaning the mercy of the father. "The stone which the builders rejected, the same is become the head of the corner" (Ps. 118, 22; see Schuon 1958: 129). In this sense Ishmael is also the figure of "the coming realm of Christ" (Boehme 1654: 40). Divine mercy makes Ishmael, the lost son, into the most-loved son whilst Isaac, who has remained by his father, is pushed into the background. 
The question arises as to how this preferential status of Ishmael, who represents Islam and who explicitly denies the divinity of Christ, is linked to the religion of Islam. Boehme answers this question with the image of the blanket with which Moses covered himself after his meeting with God (see Ex. 34, 33-35). In this sense he speaks of the Muslims, "who lie enclosed beneath the veil of Christ, as Christ did under the Levitical priesthood under Moses. And as the children of Israel were not righteous through the Law, but through he who was hidden under the Law; so too are the Muslims hidden under the true knowledge and lie as if enclosed in the womb of the mother" (Boehme 1654: 40,72). Islam is shown as having entered salvation history in the image and in the figure of Ishmael. Boehme makes this even clearer when he refers to Turks, i.e. Muslims in relation to the two lines: "Know that Cain, Ham, Ishmael and Esau, are the types of the Turks and heathen, whom God blessed in Ishmael; and gave them to possess the princely dominions in his kingdom of this world" (ibid.: 40,71) and those who are expelled from the knowledge of the sonship of God. "But the angel of the great counsel calls them by their mother, Hagar, viz. by the kingdom of nature; that she (the mother and her child) should return home to Sarah, viz. to the free, that is, to the one only God, who hath born his Son of the free" (ibid.: 40, 73). The term "free" here refers to Maria and the Son is Jesus Christ. Then Boehme explains why the Muslims do not turn to Christ but rather to the one God. Just as Ishmael did not turn to Isaac to claim a part of the father's inheritance, "even so the Turks have turned themselves from Isaac, viz. from the Son, to the Father, and will have the inheritance of God from the Father" (ibid.: 40, 74). For Boehme "when they now do call upon the Father, he heareth them only in his Son, viz. in his voice manifest in the human property, and yet they serve the Son in the Father. For we men have no other God at all without Christ the Son; for the Father hath manifested himself towards us with his voice in the Son, and heareth us only through his voice manifested in the Son" (ibid.: 40, 75-76). From this it can be concluded that: "when the Turks worship the Father, he heareth them in the Son, and receiveth them to adoption only in the Son, in whom God hath only alone once more manifested himself in the human property, and in no other property besides" (ibid.: 40, 77).

It becomes clear here that Boehme is not departing from his doctrine of the divine trinity, in the multifaceted and thorough fashion in which he developed it in his teaching on divine wisdom. The objection "Now saith reason, how can they attain to the adoption of Christ, when they will not have the Son to be the Son of God, and say that god hath no Son" (ibid.: 40, 78 ) is answered by Boehme with a reference to the Holy Spirit: "Hear, O man, Christ said, Whosoever speaketh a word against the Son of man, to him 
it shall be forgiven; but he that blasphemeth the Holy Ghost, to him it shall never be forgiven (Matt. XII. 32)" (Boehme 1654: 40, 79). He justifies this statement from Jesus as follows: "Whosoever reproacheth the humanity of Christ in ignorance, considering it as his own flesh, to him it may be forgiven; for he knoweth not what the humanity of Christ is. But he that blasphemeth the Holy Ghost, viz. the only God, who hath manifested himself in the humanity, wherein Father, Son, and Holy Ghost, are one only God, he hath no forgiveness for evermore. That is, he that rejecteth the only God, he hath quite broken himself off from him, into an ownhood of self" (ibid.: 40, 79). Boehme comes to the conclusion that the Muslims do not violate the Holy Ghost who has revealed himself to humanity. However, they turn against Jesus Christ: "Now the Turks do not blaspheme the Holy Spirit, who manifested himself in the humanity, but reproach the humanity, and say a creature cannot be God. But that God hath wrought, and done wonders in Christ, that they confess, and blaspheme not the Spirit which hath wrought in Christ, viz. in the humanity. Blindness is happened unto them, so that they walk under a veil" (ibid.: 40, 80-81). Boehme emphasizes that the Muslim denial of the divinity of Christ has only come about through God's will that this be so."He permitted the kingdom of nature to give them a doctrine of reason; seeing Christendom became blind in their reason, in respect of Christ's person, and did wrangle and jangle about Christ's humanity, and put all manner of scorn, reproach and disgrace upon his person; as it fell out among the Arians, when they denied his deity, and the bishops in their covetousness did apply his merits in his humanity for the belly's sake to their belly orders, and did practice all manner of lewdness and profaneness, even with swearing, cursing, and juggling and sorcery by his suffering and holy wounds; so that there the holy name of God, which had manifested itself in the humanity, was abused; thereupon God did hide himself from them in their understanding, so that first they became blind with the Arians in respect of the deity of Christ" (ibid.: 40, 83). Boehme sees these disputes within Christianity as the foundation of the genesis of Islam. He writes in his book "Three Principles of the Divine Essence (Drei Prinzipien Göttlichen Wesens)": "Behold, out of what are the Turks grown? Out of thy perverse Sense; when they saw that thou regardest nothing but thy Pride, and didst only contend and dispute about the Temple of Christ, that it must stand only upon Man's Foundation and Inventions, then Mahomet came forth, and found an Invention that was agreeable to Nature. Because those other followed after Covetousness, and fell off from the Temple of Christ, as also from the Light of Nature, into a Confusion of Pride... Or dost thou suppose it was for nothing? It is most certain, that the Spirit of the great World has thus set him up in great Wonders, because the other were not better; and therefore it must stand 
in the Light of Nature in the Wonders, as a God of this World, and God was near the one as the other. Thy Symbols or Signs in the Testament of Christ which thou usest (which Christ left for a Covenant) stood in Controversy, and were in Disputation, and thou didst pervert them according to thy Pride, and thou didst bend them to thy Institution, Ordinances and Appointment; thou didst no more regard the Covenant of Christ, but the Custom of Celebration or Performance of it, the Custom must serve the Turn; whereas Wood that burns not is not Fire, though when it is kindled it comes to be Fire; so also the Custom without Faith is like Wood that burns not, which they will call a Fire" (Boehme 1648: 26, 32-33). The battle went on within this weakened and tired Christianity, "there was no end to the controversies and disputations; this was stumbling block and offended the Asians, Assyrians, Egyptians, Moors, Grecians and Africans: the Indians lead a more Divine Life in their plain simplicity" (Boehme 1650: 11, 92). All nations became angry with them and said: "How can those be God's people, who are only Tyrants, Proud, Covetous, Obstinate, Stubborn, Blood-thirsty People, which practise only how to get away that which is another's, and seek after power and honour. The very heathen are not so malicious: we will not make ourselves partakers with them: God dwelleth everywhere" (ibid.: 11, 93). Thus Boehme addresses the general longing of all people for a respectable and peaceful life; they say "we call upon the only true God, who hath created all things, and go out from their Contentious Disputations: we will continue one sort of opinion, and then our country in peace, when we all believe in one God, then there is no strife, but then we shall have all one and the same will, and may live in love among one another" (ibid.: 11, 93). This human longing for the one God and for peace "hath so advanced the Turk, and brought him to great strength: so that their might is climbed up, into the Number Thousand; they rule, in one opinion, and love towards the whole world: for they are a tree of nature, which standeth also in the presence of God" (ibid.: 11,94). And, in fact, Islam, which enters salvation history through the image and figure of Ishmael, gains a meaning for Boehme for which his mystical interpretation of the banishment of Hagar and Ishmael into the desert of Beersheba provides a romantic expression. Here Hagar is not the mother of Ishmael but of nature itself. Rather than being damned to death, she bears much fruit, "which the angel brings into Abraham's tent, to be a sojourner of Christ" (Boehme 1654: 46,12). But Ishmael too here is not only the son of Hagar, but also the symbolic figure for the senses, which implies a heavenly being.

Boehme interprets the words spoken by the angel to Hagar as follows: "Arise, that is, lift up thyself to God in this resignation; and stand up in the voice which hath graciously heard thee, and looked upon thee, and take thy 
cogitations, viz. thy son, by the hand of faith; and guide and govern the powers of the mind; they shall not die, but live, and go; for I will make them a great nation; that is, to a great divine understanding and capacity in divine Mysteries; and God openeth unto nature the fountain of living water; so that it receiveth, into bottle of its essence in itself, of God's well-spring, and therewith it gives the lad, viz. the senses of the mind drink. And then God is with this lad of the thoughts, and he growth great in the wilderness, that is, in the corrupt nature; the right, discreet and intellectual child growth great in the spirit of the Lord, and becomes an archer; that is, an archer of the Lord, and his brethren; who shoots the birds of prey, and the wild beasts; understand, he shooteth down out of his spirit, with the holy spirit, the evil beasts and birds in his brethren; he teacheth them, and reproveth them with divine arrows" (ibid.: 46, 18-19). In this interpretation of the events of the desert of Beersheba it is possible to find allusions to the Arabic art of war on the one hand and to the rebirth of Ishmael in his spiritual corporeality on the other. "It is a spiritual body, which dieth not at the death of the outward man; yea, it is not buried; neither doth it arise again; but in Christ it is dead and buried, and risen again, for all, and in all, and liveth eternally, for he is passed from death to life" (ibid.: 40, 45). Thus Ishmael is the most significant symbol of Islam, both as image and figure. He incorporates all other figures within himself. Correspondingly, all believers will be invited to the marriage of the lamb at the end of time. This includes the Muslims, who will be welcomed by the angel: "But when the angel shall bid them return, they come in the humility of the lost son returning to the Father. And then there will be great joy celebrated by Christ and his angels, that the dead is made alive, and the lost is again found, and the true golden jubilee-year of the marriage of the Lamb ariseth up among them" (ibid.: 40, 90; see Rev. 19, 6-9). Thus Boehme implies that in the golden jubilee year of the marriage of the lamb, which will introduce a new, golden epoch, the unity of religions will be fulfilled.

\section{Conclusion: Jacob Boehme and the Transcendent Unity of Religions}

Boehme explains the relationship between the religions on the basis of their unity, which is grounded in the unity of God. Beginning with this basic principle, Boehme uses the figurative interpretation of the expulsion of Ishmael and Hagar to make clear that God only banishes the evil will and never the entire person. He sees the will towards God as decisive: "Whether thou hast the Name of a Christian, salvation doth not consist therein. A 
heathen and a Turk is nearer to God, as thou, who art under the Name of Christ... And if a Turk seeks God with Earnestness, though he make in blindness, yet he is of the numbers of those that are children without understanding, and he reacheth to God with the children" (Boehme 1650: 6, 21). Principally Boehme's view is that: „there is no respect of persons or of names and opinions with God: he seeketh the Abyss of the heart" (ibid.: 11, 91). Correspondingly, his position towards the relation between Christianity and Islam concludes with the view that "if we truly compare counterfeit Christendom and the Turks together, and look upon them aright, then we see that they (since the Turks departed from them) have been but one people, before God in righteousness and holiness, with different names" (Boehme 1654: 40, 92). The basis for this view is the oneness of God and it is the recognition of this oneness that leads to the recognition of the transcendent unity of religions, a unity that God himself always foresaw: "Most certainly there is but one God; but when the veil is put away from thy eyes, so that thou seest and knowest him, then thou wilt also see and know all thy brethren, whether they be Christians, Jews, Turks or Heathen" (Boehme 1656: 11, 34).

\section{Appendix: Jacob Boehme's Biblical Sources}

\section{Old Testament}

Gen. 16. 1-16: "Now Sarai Abram's wife bare him no children: and she had a handmaid, an Egyptian, whose name was Hagar. And Sarai said unto Abram, Behold now, the Lord hath restrained me from bearing: I pray thee, go in unto my maid; it may be that I may obtain children by her. And Abram hearkened to the voice of Sarai. And Sarai Abram's wife took Hagar her maid the Egyptian, after Abram had dwelt ten years in the land of Canaan, and gave her to her husband Abram to be his wife. And he went in unto Hagar, and she conceived: and when she saw that she had conceived, her mistress was despised in her eyes. And Sarai said unto Abram, My wrong be upon thee: I have given my maid into thy bosom; and when she saw that she had conceived, I was despised in her eyes: the Lord judge between me and thee. But Abram said unto Sarai, Behold, thy maid is in thy hand; do to her as it pleaseth thee. And when Sarai dealt hardly with her, she fled from her face. And the angel of the Lord found her by a fountain of water in the wilderness, by the fountain in the way to Shur. And he said, Hagar, Sarai's maid, whence camest thou? And whither wilt thou go? And she said, I flee from the face of my mistress Sarai. And the angel of the Lord said unto her, Return to thy mistress, and submit thyself under her hands. And the angel of the Lord said 
unto her, I will multiply thy seed exceedingly, that it shall not be numbered for multitude. And the angel of the Lord said unto her, Behold, thou art with child, and shalt bear a son, and shalt call his name Ishmael; because the Lord hath heard thy affliction. And he will be a wild man; his hand will be against every man, and every man's hand against him; and he shall dwell in the presence of all his brethren. And she called the name of the Lord that spake unto her, Thou God seest me: for she said, Have I also here looked after him that seeth me? Wherefore the well was called Beer-la-hai-roi; behold, it is between Kadesh and Bered. And Hagar bare Abram a son: and Abram called his son's name, which Hagar bare, Ishmael. And Abram was fourscore and six years old, when Hagar bare Ishmael to Abram".

Gen. 17, 18-20: "And Abraham said unto God, O that Ishmael might live before thee! And God said, Sarah thy wife shall bear thee a son indeed; and thou shalt call his name Isaac: and I will establish my covenant with him for an everlasting covenant, and with his seed after him. And as for Ishmael, I have heard thee: Behold, I have blessed him, and will make him fruitful, and will multiply him exceedingly; twelve princes shall he beget, and I will make him a great nation".

Gen. 21, 1-21: "And the Lord visited Sarah as he had said, and the Lord did unto Sarah as he had spoken. For Sarah conceived, and bare Abraham a son in his old age, at the set time of which God had spoken to him. And Abraham called the name of his son that was born unto him, whom Sarah bare to him, Isaac. And Abraham circumcised his son Isaac being eight days old, as God had commanded him. And Abraham was an hundred years old, when his son Isaac was born unto him. And the child grew, and was weaned: and Abraham made a great feast the same day that Isaac was weaned. And Sarah saw the son of Hagar the Egyptian, which she had born unto Abraham, mocking. Wherefore she said unto Abraham, Cast out this bondwoman and her son: for the son of this bondwoman shall not be heir with my son, even with Isaac. And the thing was very grievous in Abraham's sight because of his son. And God said unto Abraham, Let it not be grievous in thy sight because of the lad, and because of thy bondwoman; in all that Sarah hath said unto thee, hearken unto her voice; for in Isaac shall thy seed be called. And also of the son of the bondwoman will I make a nation, because he is thy seed. And Abraham rose up early in the morning, and took bread, and a bottle of water, and gave it unto Hagar, putting it on her shoulder, and the child, and sent her away: and she departed, and wandered in the wilderness of Beer-sheba. And the water was spent in the bottle, and she cast the child 
under one of the shrubs. And she went, and sat her down over against him a good way off, as it were a bowshot: for she said, Let me not see the death of the child. And she sat over against him, and lifted up her voice, and wept. And God heard the voice of the lad; and the angel of God called to Hagar out of heaven, and said unto her, What aileth thee, Hagar? Fear not; for god hath heard the voice of the lad where he is. Arise, lift up the lad, and hold him in thine hand; for I will make him a great nation. And God opened her eyes, and she saw a well of water; and she went, and filled the bottle with water, and gave the lad drink. And God was with the lad; and he grew, and dwelt in the wilderness, and became an archer. And he dwelt in the wilderness of Paran: and his mother took him a wife out of the land of Egypt".

\section{New Testament}

Gal. 4, 21-31: "Tell me, ye that desire to be under the law, do ye not hear the law? For it is written, that Abraham had two sons, the one by a bondmaid, the other by a free woman. But he who was of the bondwoman was born after the flesh; but he of the freewoman was by promise. Which things are an allegory: for these are the two covenants; the one from the mount Sinai, which gendereth the bondage, which is Agar. For this Agar is mount Sinai in Arabia, and answereth to Jerusalem which now is, and is in bondage with her children. But Jerusalem which is above is free, which is the mother of us all. For it is written, Rejoice, thou barren that bearest not; break forth and cry, thou that travailest not: for the desolate hath many more children than she which hath an husband. Now we, brethren, as Isaac was, are the children of promise. But as then he that was born after the flesh persecuted him that was born after the Sprit, even so it is now. Nevertheless what saith the scripture? Cast out the bondwoman and her son: for the son of the bondwoman shall not be heir with the son of the freewoman. So then, brethren, we are not children of the bondwoman, but of the free".

Luke 15, 11-32: "A certain man had two sons: And the younger of them said to his father, Father, give me the portion of goods that falleth to me. And he divided unto them his living. And not many days after the younger son gathered all together, and took his journey into a far country, and there wasted his substance with riotous living. And when he had spent all, there arose a mighty famine in that land; and he began to be in want. And he went and joined himself to a citizen of the country; and he sent him into his fields to feed swine. And he would fain have filled his belly with the husks that the swine did eat: and no man gave unto him. And when he came to himself, he said, How many hired servants of my father's have bread enough and to spare, 
and I perish with hunger! I will arise and go to my father, and will say unto him, Father, I have sinned against heaven, and before thee, and am no more worthy to be called thy son: make me as one of thy hired servants. And he arose, and came to his father. But when he was yet a great way off, his father saw him, and had compassion, and ran, and fell on his neck, and kissed him. And the son said unto him, Father, I have sinned against heaven, and in thy sight, and am no more worthy to be called thy son. But the father said to his servants, Bring forth the best robe, and put it on him; and put a ring on his hand, and shoes on his feet: And bring hither the fatted calf, and kill it; and let us eat, and be merry: For this my son was dead, and is alive again; he was lost, and is found. And they began to be merry. Now his elder son was in the field: and as he came and drew nigh to the house, he heard music and dancing. And he called one of the servants, and asked what these things meant. And he said unto him, Thy brother is come; and thy father hath killed the fatted calf, because he hath received him safe and sound. And he was angry, and would not go in: therefore came his father out, and entreated him. And he answering said to his father, Lo, these many years do I serve thee, neither transgressed I at any time thy commandment: and yet thou never gavest me a kid, that I might make merry with my friends: But as soon as this thy son was come, which hath devoured thy living with harlots, thou hast killed for him the fatted calf. And he said unto him, son, thou art ever with me, and all that I have is thine. It was meet that we should make merry, and be glad: for this thy brother was dead, and is alive again; and was lost, and is found".

Received: March $4^{\text {th }}, 2016$.

Accepted: April 16 ${ }^{\text {th }}, 2016$.

\section{References}

Benz, Ernst (1935), Die Geschichtsmetaphysik Jakob Böhmes in Deutsche Vierteljahrsschrift für Literaturwissenschaft und Geistesgeschichte, 13: 421-455.

Benz, Ernst (1937), Der vollkommene Mensch nach Jacob Böhme, Stuttgart, Kohlhammer.

Boehme, Jacob (1647), The Clavis or Key, Translated by John Sparrow, London, Blunden.

Boehme, Jacob (1648), A Description of the Three Principles of the Divine Essence, Translated by John Sparrow, London, Blunden.

Boehme, Jacob (1650), The Threefold Life of Man, London, Blunden.

Boehme, Jacob (1651), Signatura Rerum or the Signature of All Things, London, Calvert. 
Boehme, Jacob (1654), Mysterium Magnum and Four Tables of Divine Revelation, London, Blunden.

Boehme, Jacob (1655), Concerning the Election of Grace, Translated by John Sparrow, London, Calvert.

Boehme, Jacob (1656), The Aurora, Translated by John Sparrow, London, Lodowick Lloyd.

Boehme, Jacob (1659), Of the Becoming Man or Incarnation of Jesus Christ, London, Lodowick Lloyd.

Boehme, Jacob (1920), Six Theosophic Points and other Writings, Translated by John Rolleston Earle, New York, Alfred A. Knopf.

Bonheim, Günther (1992), Zeichendeutung und Natursprache. Ein Versuch über Jacob Böhme, Würzburg, Königshausen.

Cuniberto, Flavio (2000), Jakob Böhme, Brescia, Morcelliana.

Deghaye, Pierre (1985), Dieu ou la doctrine de Jacob Boehme, Paris, Michel.

Hamberger, Julius (1844), Die Lehre des deutschen Philosophen Jakob Böhme, München, Verlag der literarisch-artistischen Anstalt.

Hankamer, Paul (1924), Jakob Böhme. Gestalt und Gestaltung, Bonn, Friedrich Cohen.

Hiebsch, Sabine (2002), Figura ecclesiae: Lea und Rachel in Martin Luthers Genesispredigten, Münster, Lit. Koyré, Alexandre (1929), La Philosophie de Jacob Boehme, Paris, J. Vrin.

Hilgenfeld, Hartmut (1971), Mittelalterlich-traditionelle Elemente in Luthers Abendmahlschrift, Zürich, Theologischer Verlag.

Krause, Gerhard (1960), Studien zu Luthers Auslegung der kleinen Propheten, Tübingen, Mohr.

Peuckert, Will-Erich (1924), Das Leben Jakob Böhmes, Jena, Eugen Diederichs.

Pietsch, Roland (1999), Jakob Böhmes Lehre von der göttlichen Weisheit und der himmlischen Jungfrau Sophia in Schriften der Sudetendeutschen Akademie der Wissenschaften und Künste, vol. 20: Vorträge und Abhandlungen aus geisteswissenschaftlichen Bereichen, 205-228, München, Sudetendeutsche Akademie der Wissenschaften und Künste.

Schuon, Frithjof (1985), Christianity / Islam - Essays on Esoteric Ecumenism, Bloominton, World Wisdom.

Solms-Rödelheim, Günther Graf zu (1962), Die Grundvorstellungen Jakob Böhmes und ihre Terminologie, München.

Stoudt, John Joseph (1957), Sunrise to Eternity: A Study in Jacob Boehme's Life and Thought, Philadelphia, University of Pennsylvania Press.

Walsh, David A. (1983), The Mysticism of Innerwordly Fulfillment: A Study of Jacob Boehme, Gainsville, University of Florida Press.

Weeks, Andrews (1991), Boehme: An Intellectual Biography of the Seventeenth-Century Philosopher and Mystic, Albany, State University of New York Press. 